\title{
Effect of growth hormone hypersecretion on the cardiovascular system
}

\author{
Vplyv hypersekrécie rastového hormónu na kardiovaskulárny systém
}

\author{
Smaha J, Kužma M, Payer J \\ V. interná klinika LF UK a UNB Bratislava, Slovenská republika
}

\begin{abstract}
Smaha J, Kuzma M, Payer J. Effect of growth hormone hypersecretion on the cardiovascular system. Cardiology Lett. 2020;29(4):243-247

Abstract. Growth hormone (GH) and insulin-like growth factor 1 (IGF-1) are molecules whose overproduction in patients with acromegaly leads to the development of cardiovascular comorbidities. The extent of the disease depends on the length of exposure of myocardial cells and endothelial cells to excessive concentrations of $\mathrm{GH} / \mathrm{IGF}-1$. However, the coexistence of other classical cardiovascular risk factors is also important. The most common cardiovascular comorbidities are arterial hypertension, acromegalic cardiomyopathy, valvular heart disease, arrhythmias and coronary artery disease. When a typical echocardiographic image of cardiomyopathy is present rare causes of cardiomyopathy should be considered, especially in young adults. Studies from recent years have shown a significant decrease in cardiovascular morbidity and mortality in patients with biochemically well-controlled disease. This paper summarizes the most commonly occurring cardiovascular comorbidities in patients with acromegaly, describing their pathophysiology and clinical management with an emphasis on early and adequate diagnosis. Fig. 1, Tab. 2, Ref. 28, on-line full text (Free, PDF) www.cardiologyletters.sk Key words: growth hormone - insulin-like growth factor 1 - acromegaly - hypertension - atherosclerosis - cardiomyopathy
\end{abstract}

Smaha J, Kužma M, Payer J. Vplyv hypersekrécie rastového hormónu na kardiovaskulárny systém. Cardiology Lett. 2020;29(4):243-247

Abstrakt. Rastový hormón (GH) a inzulínu podobný rastový faktor 1 (IGF-1) sú molekuly, ktorých nadprodukcia u pacientov s akromegáliou vedie k rozvoju kardiovaskulárnych komorbidít. Rozsah postihnutia u pacienta závisí od dĺžky expozície buniek myokardu a endotelu ciev nadmerným koncentráciám pôsobkov somatotropných buniek. Dôležitá je však aj koexistencia klasických kardiovaskulárnych rizikových faktorov. Najčastejšími kardiovaskulárnymi komorbiditami sú artériová hypertenzia, akromegalická kardiomyopatia, valvulopatie, arytmie a koronárna choroba srdca. Pri typickom echokardiografickom obraze kardiomyopatie treba mysliet' predovšetkým u mladých dospelých pacientov aj na zriedkavé príčiny ako je akromegália. Štúdie z ostatných rokov preukázali významný pokles kardiovaskulárnej morbidity a mortality u pacientov s biochemicky dobre kontrolovaným ochorením. Práca sumarizuje najčastejšie sa vyskytujúce kardiovaskulárne komorbidity u pacientov s akromegáliou, popisuje ich patofyziológiu a klinický manažment s dôrazom na skorú a adekvátnu diagnostiku. Obr. 1, Tab. 2, Lit. 28, on-line full text (Free, PDF) www.cardiologyletters.sk Klúčové slová: rastový hormón - IGF-1 - akromegália - hypertenzia - ateroskleróza - kardiomyopatia

Efekt rastového hormónu $(\mathrm{GH})$ na kardiovaskulárny systém (KVS) sa považuje za jednu $\mathrm{z}$ hlavných príčin morbidity a mortality pacientov s akromegáliou. GF a IGF-1 účinkujú

Z V. internej kliniky LF UK a UNB Bratislava, Slovenská republika Do redakcie došlo dňa 1 . júna 2020; prijaté dňa 17. júla 2020 na kardiovaskulárne funkcie priamo a nepriamo. GH aj IGF-1 majú priamy účinok na funkcie obličky, IGF-1 priamo pôsobí na bunky myokardu a endotelu ciev (obrázok 1). Dôležitým

Adresa pre korešpondenciu: MUDr. Juraj Smaha, V. interná klinika LF UK a UNB Bratislava, Ružinovská 6, 82606 Bratislava, Slovenská republika, e-mail: jurajsmaha@gmail.com 


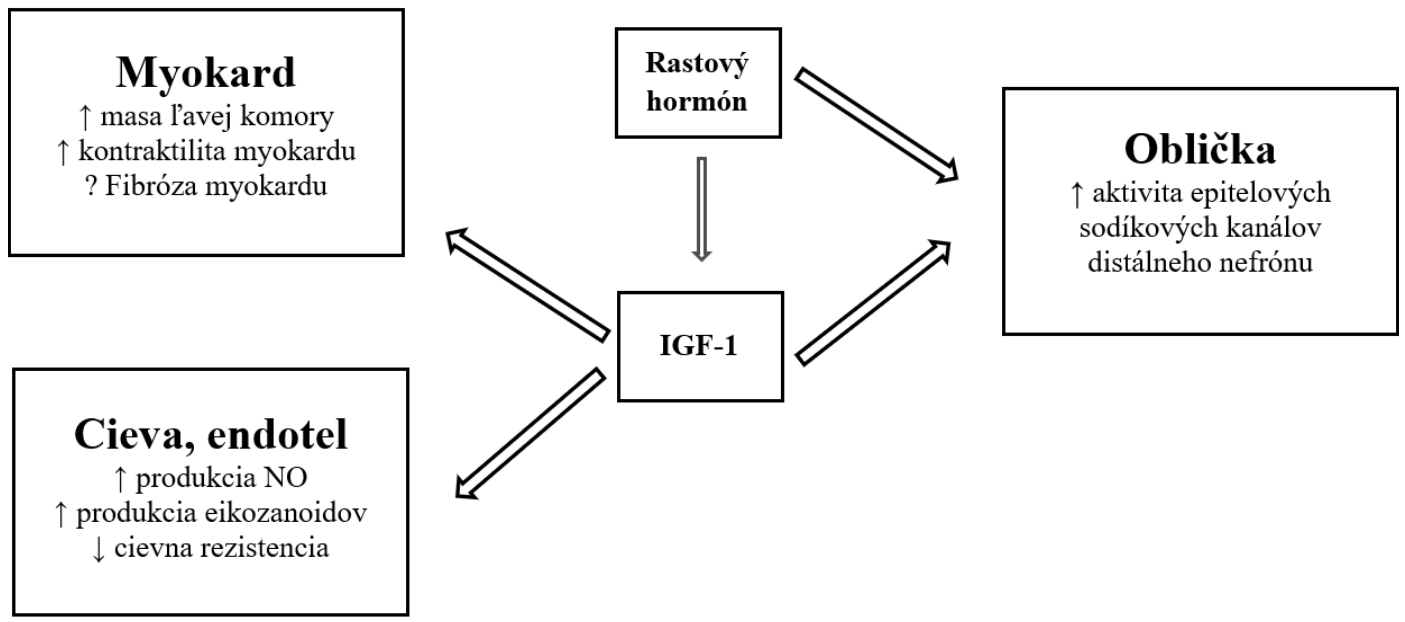

Obrázok 1 Efekt GH a IGF-1 na fungovanie kardiovaskulárneho systému. Upravené podla 16

Figure 1 The effect of GH and IGF-1 on functions of the cardiovascular system. Modified according to 16

rizikovým faktorom je dížka trvania ochorenia. Akromegália je často poddiagnostikované ochorenie, časový interval od začiatku ochorenia po diagnózu je $\mathrm{v}$ priemere osem rokov. $\mathrm{V}$ čase diagnózy má $60 \%$ pacientov známky hypertrofie lavej komory a $40 \%$ artériovú hypertenziu (1). Na Slovensku zatial nemáme $\mathrm{k}$ dispozícii žiadne epidemiologické štúdie skúmajúce prevalenciu kardiovaskulárnych ochorení u týchto pacientov. V súčasnosti je u nás asi 450 pacientov s diagnózou akromegálie. Do doposial najväčšej štúdie venovanej akromegálii a jej efektu na riziko fraktúr bolo zaradených 106 pacientov, z ktorých 19 malo diagnostikovanú akromegalickú kardiomyopatiu (echokardiograficky verifikovanú) a 54 malo diagnostikovanú artériovú hypertenziu (2). V tejto štúdii sa prevalencia iných KVS ochorení neskúmala. Vzhladom na pomerne vysokú morbiditu a mortalitu, ku ktorej v dôsledku KVS ochorení u pacientov $s$ akromegáliou dochádza, sú takéto štúdie do budúcnosti vel'mi vítané.

\section{Artériová hypertenzia}

Artériová hypertenzia je najčastejšia KVS komorbidita, ktorá sa objavuje u $18 \%$ až $60 \%$ pacientov (3). Prevažne ide o zvýšenie diastolického tlaku krvi. Takmer $50 \%$ pacientov patrí medzi tzv. "non-dippers“ - osoby bez adekvátneho poklesu tlaku krvi v nočných hodinách. Ide o výrazne vyššie percento ako $\mathrm{v}$ bežnej populácii a dáva sa do súvislosti so zvýšenou prevalenciou obštrukčného spánkového apnoe u akromegalikov (4). Presný patofyziologický mechanizmus rozvoja hypertenzie nie je známy, ale akceptuje sa názor, že ide o súhrn viacerých faktorov. Ako základný patofyziologický mechanizmus sa predpokladá antinatriuretický efekt GH mediovaný cez epitelové sodíkové kanály zberného kanálika obličky so sekundárnou expanziou extracelulárnej tekutiny. Väčšina štúdií nepreukázala, že by hodnota sérového GH/IGF-1 v čase diagnózy súvisela s prítomnostou alebo závažnostou hypertenzie (5). Hypertenziu u akromegalikov možno liečit štandardnou antihypertenzívnou liečbou. Zaujímavou molekulou je kálium šetriace diuretikum amilorid. Miesto pôsobenia amiloridu je práve epitelový sodíkový kanál zberných kanálikov obličky, ktorý má klúčovú úlohu v patomechanizme rozvoja hypertenzie u týchto pacientov (6). Liečba ACE inhibítormi a sartanmi viedla $\mathrm{v}$ porovnaní $\mathrm{s}$ inými skupinami antihypertenzív $\mathrm{k}$ zlepšeniu sledovaných parametrov na MR vyšetrení myokardu (7). Čo sa týka špecifickej liečby akromegálie, chirurgické odstránenie hormonálne aktívneho nádoru hypofýzy, liečba somatostatínovými analógmi aj liečba pegvisomantom vedie u mnohých pacientov $\mathrm{k}$ významnému zníženiu systolického, ako aj diastolického tlaku krvi (8). $\mathrm{K}$ dekompenzácii dlhotrvajúcej stabilnej artériovej hypertenzie môže viest̉ aj zhoršenie existujúcich komorbidít, ako sú napríklad hypertrofia myokardu a/alebo spánkové apnoe. Obštrukčné spánkové apnoe je prítomné až u 80 \% novodiagnostikovaných akromegalikov a zároveň je nezávislým rizikovým faktorom kardiovaskulárnych ochorení a výrazne prispieva k rozvoju artériovej hypertenzie (9). U každého pacienta s akromegáliou treba aktívne pátrat po prejavoch obštrukčného spánkového apnoe.

\section{Akromegalická kardiomyopatia}

Pozitívny efekt GH/IGF-1 na myokard je známy zo štúdií skúmajúcich efekt podávania $\mathrm{GH}$ u pacientov s jeho deficitom $(10,11)$. Avšak výsledkom pôsobenia nadmerného 
množstva GH a IGF-1na bunku kardiomyocytu je depozícia extracelulárneho kolagénu, degradácia myofibríl, lymfomonocytárna infiltrácia a následná nekróza, ktorá spôsobuje rozvoj špecifickej kardiomyopatie. Prevalencia hypertrofie myokardu u pacientov s neliečenou alebo neadekvátne kontrolovanou akromegáliou môže byṫ 70 - 90 \% (12). Akromegalická kardiomyopatia sa môže rozvinút aj u pacientov bez akýchkolvek iných kardiovaskulárnych rizikových faktorov (13). Prirodzený vývoj akromegalickej kardiomyopatie prebieha $\mathrm{v}$ troch fázach. $\mathrm{V}$ prvej včasnej fáze, ktorá začína už u mladých pacientov, možno pozorovat iniciálnu hypertrofiu, nárast srdcovej frekvencie, zvýšenie vývrhového objemu srdca a rozvoj hyperkinetického syndrómu. V druhej fáze sa stáva hypertrofia zretelnejšou, postihuje obe komory, ale výraznejšie lavú (LK), dochádza $k$ významnej diastolickej dysfunkcii a intolerancii námahy. $\mathrm{V}$ tretej, konečnej fáze neliečeného ochorenia je už prítomná tažká systolická aj diastolická dysfunkcia a rozvinutý klinický obraz kongestívneho srdcového zlyhávania (14). Pacienti bývajú často diagnostikovaní $\mathrm{v}$ druhej fáze ochorenia, kedy porucha diastolickej funkcie limituje ich schopnost' fyzickej aktivity. Skorý začiatok špecifickej liečby a normalizácia hormonálneho statusu bráni rozvoju kardiomyopatie a vedie $\mathrm{k}$ redukcii hypertrofie LK a zlepšeniu diastolickej aj systolickej funkcie LK. Podobný efekt má u pacientov aj chirurgické odstránenie adenómu hypofýzy, avšak v porovnaní s pacientmi na liečbe somatostatínovými analógmi nedochádza $\mathrm{k}$ jasnému zlepšeniu systolickej funkcie LK (15). Efekt liečby však okrem adekvátnej hormonálnej kontroly závisí aj od veku pacienta, trvania ochorenia a manažmentu ostatných komorbidít zvyšujúcich KVS riziko (glukózový metabolizmus, dyslipidémia, obezita, fajčenie, artériová hypertenzia). Odporúča sa realizovat echokardiografické vyšetrenie (ECHO) u každého pacienta $\mathrm{v}$ čase diagnostiky akromegálie (zhodnotenie hypertrofie, systolickej a diastolickej funkcie LK, valvulopatie). V prípade normálneho vstupného nálezu sa $\mathrm{ECHO} u$ pacienta s dobre biochemicky kontrolovaným ochorením nemusí opakovat'. U pacientov s ECHO abnormalitami treba vyšetrenie každoročne zopakovat (16). Zlatým štandardom pre vyšetrenie masy lavej komory je MR myokardu s podaním kontrastnej látky (gadolínium). Napriek vyššej presnosti, reproducibilite a nižšej variabilite oproti echokardiografickému vyšetreniu sa paušálne u pacientov na zhodnotenie hypertrofie myokardu neodporúča vzhladom na nižšiu dostupnost’ a vyššiu cenu (13).

\section{Ochorenia srdcových chlopní}

Postihnutie srdcových chlopní je častejšie ako u bežnej populácie a je priamym dôsledkom pôsobenia GH. Určitá forma valvulopatie môže byṫ v čase diagnózy prítomná u $75 \%$ pacientov (17). Hormonálna nadprodukcia somatotropných buniek vedie $\mathrm{k}$ nadmernej expresii metaloproteináz, syntéze proteoglykánu, depozícii kolagénu a mukopolysacharidov v oblasti cípov chlopne. Primárne sú postihnuté mitrálna a aortálna chlopňa, postihnutie sa najčastejšie prejavuje mitrálnou a aortálnou regurgitáciou (18). K aortálnej regurgitácii môže prispievat aj ektázia kmeňa aorty, popisovaná až u $26 \%$ pacientov (19). Závažnost' chlopňovej chyby je priamoúmerná trvaniu akromegálie. Zaujímavostou je, že liečba somatostatínovými analógmi vedie $\mathrm{k}$ regresii hypertrofie LK, avšak nemá vplyv na zlepšenie funkcie srdcovej chlopne (20). Na rozdiel od hypertrofie L'K je teda chlopňová chyba u pacientov s akromegáliou pravdepodobne ireverzibilná a farmakologická liečba môže iba zabránit jej dalš̌iemu zhoršeniu. V prípade existujúcej chlopňovej chyby sú vhodné pravidelné ECHO kontroly.

\section{Arytmie}

Vzhladom na pomerne vysokú frekvenciu fibrotických zmien myokardu (zistených na základe analýzy vzoriek získaných pri autopsii) sa u pacientov $\mathrm{s}$ akromegáliou predpokladá určitý proarytmogeńny potenciál (21). Komorové extrasystoly, paroxyzmálna fibrilácia predsiení, paroxyzmálne supraventrikulárne tachykardie, sicksinus syndróm aj komorové tachykardie sú relatívne často popisované u pacientov $s$ akromegáliou, najmä počas fyzickej zátaže. V prípade klinického podozrenia alebo abnormálneho nálezu na 12-zvodovom EKG by mali pacienti absolvovat 24-hodinový monitoring EKG. Vo väčšine prípadov sa však klinicky významná arytmia nepreukáže (22). U akromegalikov sa môže objavit’ aj špecifická abnormalita rytmu - tzv. ventrikulárna dyssynchronicita, ktorá sa objavuje nezávisle od prítomnosti kardiovaskulárnych rizikových faktorov, dížky ochorenia, či veku v čase diagnózy. Predpokladá sa priamy hormonálny vplyv na synchronicitu myokardu (23). U pacientov sa relatívne častejšie môže objavit predížený QT interval. Vzhladom na špecifickú liečbu akromegálie môže QT interval predlžovat’ liečba pasireotidom (24).

\section{Ateroskleróza a koronárna choroba srdca}

Akromegália súvisí s mnohými rizikovými faktormi rozvoja aterosklerózy a koronárnej choroby srdca - artériová hypertenzia, diabetes mellitus, dyslipidémia. Napriek tomu väčšina štúdií do dnešného dňa nepreukázala vyššiu prevalenciu koronarosklerózy v porovnaní s bežnou populáciou. $\mathrm{V}$ dodnes najväčšej realizovanej štúdii hodnotiacej obsah kalcia v stene koronárnej artérie sa nepreukázal významný rozdiel medzi bežnou populáciou a pacientmi s aktívnou akromegáliou (25). Riziko aterosklerózy u akromegalikov lepšie koreluje s prítomnostou klasických rizikových fakto- 
rov KVS ochorení (fajčenie, obezita, inzulínová rezistencia, hyperglykémia, poruchy metabolizmu lipidov) než s nadprodukciou GH/IGF-1. Manažment týchto rizikových faktorov podla existujúcich odporúčaní pre bežnú populáciu prispieva k zníženiu celkovej kardiovaskulárnej zátaže u pacientov s akromegáliou.

\section{Záver}

Ochorenia kardiovaskulárneho systému sú najčastejšou príčinou morbidity a po onkologických ochoreniach druhou najčastejšou príčinou mortality u pacientov $\mathrm{s}$ akromegáliou. Adekvátny manažment kardiovaskulárnych komorbidít u týchto pacientov pozostáva $\mathrm{z}$ dvoch pilierov:
- Skorá diagnostika akromegálie s dobrou biochemickou kontrolou dysregulovanej somatotropnej hormonálnej osi - biochemicky dobre kontrolované ochorenie je jedným $\mathrm{z}$ hlavných determinantov redukcie mortality a morbidity u pacientov s akromegáliou (26). Efekt chirurgického odstránenia hormonálne aktívneho adenómu hypofýzy a farmakologickej liečby analógmi somatostatínu a pegvisomantom na kardiovaskulárny systém je zhrnutý v tabulke $\mathbf{1}$.

- Včasná diagnostika kardiovaskulárnej komorbidity, optimálny farmakologický a nefarmakologický manažment kardiovaskulárnych ochorení podla existujúcich odporúčaní so zabezpečením pravidelných kontrol internistom/ kardiológom. Navrhovaný algoritmus skríningu kardiovaskulárnych komorbidít $\mathrm{u}$ pacientov s akromegáliou je uvedený v tabulke $2(4,16,27,28)$.

Tabulka 1 Efekt špecifickej terapie na kardiovaskulárny systém. Upravené podla 21

Table 1 The effect of specific therapy on the cardiovascular system. Modified according to 21

\begin{tabular}{lll}
\hline Transsfenoidálna chirurgia & Somatostatínové analógy & Pegvisomant \\
\hline$\downarrow$ inzulínová rezistencia & $\downarrow$ LDL, VLDL, Lp(A), $\uparrow$ HDL & glukózová tolerancia \\
$\downarrow$ TG, VLDL, Lp(A) & $\uparrow$ inzulínová senzitivita & $\downarrow$ tlak krvi \\
$\uparrow$ HDL & $\uparrow$ sekrécia inzulínu & $\downarrow$ masa LK, $\uparrow$ EF LK \\
$\downarrow$ masa LK, $\uparrow$ EF LK & $\downarrow$ tlak krvi & $\uparrow$ diastolická funkcia \\
$\uparrow$ diastolická funkcia & $\downarrow$ masa LK, $\uparrow$ EF LK & $\downarrow$ hrúbka intima-média \\
& $\uparrow$ diastolická funkcia & \\
& $\downarrow$ srdcová frekvencia & \\
& $\downarrow$ počet komorových extrasystol & \\
& $\downarrow$ QT interval & \\
\hline
\end{tabular}

Tabulka 2 Navrhovaný algoritmus skríningu kardiovaskulárnych komorbidít u pacientov s akromegáliou

Table 2 Suggested algorithm for screening of the cardiovascular comorbidities in patients with acromegaly

\begin{tabular}{|c|c|c|}
\hline Komorbidita & Skríningové vyšetrenie & Periodicita vyšetrenia \\
\hline \multirow[t]{2}{*}{ Artériová hypertenzia } & Ambulantné meranie krvného tlaku & $\begin{array}{l}\mathrm{V} \text { čase diagnózy, následne každých } 6 \text { mesiacov; vždy pri zmene } \\
\text { antihypertenzívnej liečby }\end{array}$ \\
\hline & Dotazník The Epworth Sleepiness Scale (ESS) & Vyhodnotenie dotazníka raz ročne \\
\hline Akromegalická kardiomyopatia & Echokardiografické vyšetrenie & $\begin{array}{l}\text { V čase diagnózy; ak je prítomný fyziologický nález netreba opakovat; } \\
\text { ak je prítomný abnormálny nález, tak opakovat každoročne; vhodné } \\
\text { každoročné vyšetrenie aj v prípade neadekvátne biochemicky } \\
\text { kontrolovaného ochorenia }\end{array}$ \\
\hline Valvulopatie & Echokardiografické vyšetrenie & $\begin{array}{l}\text { V čase diagnózy; ak je prítomný fyziologický nález netreba opakovat; } \\
\text { ak je prítomný abnormálny nález, tak opakovat každoročne; vhodné } \\
\text { každoročné vyšetrenie aj v prípade neadekvátne biochemicky } \\
\text { kontrolovaného ochorenia }\end{array}$ \\
\hline Arytmie & 12-zvodové EKG & $\begin{array}{l}\text { V čase diagnózy; vždy pri podozrivej symptomatológii alebo fyzikálnom } \\
\text { náleze; opakovat každoročne, ak je vstupné EKG abnormálne, respektíve } \\
\text { zvážit 24-hodinový EKG Holter monitoring }\end{array}$ \\
\hline \multirow[t]{2}{*}{ Ateroskleróza } & Glykémia nalačno & $\begin{array}{l}\text { V čase diagnózy; opakovat každých } 6 \text { mesiacov osobitne pri biochemicky } \\
\text { neadekvátne kontrolovanom ochorení alebo pri liečbe somatostatínovými } \\
\text { analógmi; glykovaný hemoglobín každých } 6 \text { mesiacov, ak má pacient } \\
\text { diabetes alebo prediabetes }\end{array}$ \\
\hline & Lipidogram & $\begin{array}{l}\text { V čase diagnózy; opakovat každých } 6 \text { mesiacov osobitne pri biochemicky } \\
\text { neadekvátne kontrolovanom ochorení }\end{array}$ \\
\hline
\end{tabular}




\section{Literatúra}

1. El MehraouiO, Derakou N, Ezzerrouqi A, et al. Acromegaly complications at the time of diagnosis. Endocrine Abstracts. 2019;63:P680.

2. Kužma M, Vaňuga P, Ságová I, et al. Non-invasive DXA-derived bone structure assessment of acromegaly patients: a crosssectional study. Eur J Endocrinol. 2019;180:201-211.

3. Bondanelli M, Ambrosio MR, degli Uberti EC, et al. Pathogenesis and prevalence of hypertension in acromegaly. Pituitary. 2001;4:239-249.

4. Ramos-Levi AM, Marazuela M. Bringing cardiovascular comorbidities in acromegaly to an update. How should we diagnose and manage them? Front Endocrinol. 2019;10: 1-11.

5. Mercado M, Espinosa de los Monteros AL, Sosa E, et al. Clinicalbiochemical correlations in acromegaly at diagnosis and the real prevalence of biochemically discordant disease. Horm Res. 2004;62:293-299.

6. Kamenicky P, Blanchard A, Frank M, et al. Body fluid expansion in acromegaly is related to enhanced epithelial sodium channel (ENaC) activity. J Clin Endocrinol Metab. 2011;96:2127-2135.

7. Thomas JDJ, Dattani A, Zemrak F, et al. Renin-angiotensin system blockade improves cardiac indices in acromegaly patients. Exp Clin Endocrinol Diabetes. 2017;125:365-367.

8. González B, Vargas G, de Los Monteros ALE, et al. Persistence of diabetes and hypertension after multimodal treatment of acromegaly. J Clin Endocrinol Metab. 2018;103:2369-2375.

9. Guo X, Gao L, Zhao Z, et al. Characteristics of the upper respiratory tract in patients with acromegaly and correlations with obstructive sleep apnea/hypopnea syndrome. Sleep Med. 2018;48:27-34.

10. Dlesk A, Kamensky G, Lazurova I, et al. The effect of growth hormone replacement therapy on the morphological and functional changes in the left ventricle in patients with adult-onset growth hormone deficiency. Wien Klin Wochenschr. 2014;126:480-484.

11. Lazurova I, Pura M, Wagnerova $\mathrm{H}$, et al. Effect of growth hormone replacement therapy on plasma brain natriuretic peptide concentration, cardiac morphology, and function in adults with growth hormone deficiency. Exp Clin Endocrinol Diabetes. 2010;118:172-176.

12. Bogazzi F, Lombardi M, Strata E, et al. High prevalence of cardiac hypertrophy without detectable signs of fibrosis in patients with untreated active acromegaly: an in vivo study using magnetic resonance imaging. Clin Endocrinol. 2008;68:361-368.

13. Godberg MD, Vadera N, Yandrapalli S, et al. Acromegalic cardiomyopathy: an overview of risk factors, clinical manifestations and therapeutic options. Cardiol Rev. 2018;26:307-311.
14. Colao A, Ferone D, Marzullo P, et al. Systemic complications of acromegaly: epidemiology, pathogenesis and management. Endocr Rev. 2004;25:102-152.

15. Colao A, Pivonello R, Galderisi M, et al. Impact of treating acromegaly first on surgery or somatostatin analogs on cardiomyopathy. J Clin Endocrinol Metab. 2008;93:2639-2646.

16. Gadelha MR, Kasuki L, Lim DS, et al. Systemic complications of acromegaly and the impact of the current treatment landscape: an update. Endocrine Reviews. 2019;40:268-332.

17. Colao A, Spinelli L, Marzullo P, et al. High prevalence of cardiac valve disease in acromegaly: An observational, analytical, casecontrol study. J Clin Endocrino lMetab. 2003;88:196-201.

18. Pereira AM, van Thiel JR, Lindner F. Increased prevalence of regurgitant valvular heart disease in acromegaly. J Clin Endocrinol Metab. 2004;89:71-75.

19. van der Klaauw JJ, Bax JW, Roelfsema GB, et al. Increased aortic root diameters in patients with acromegaly. Eur J Endocrinol. 2008;159:97-103.

20. Colao A, Marek J, Goth MI, et al. No greater incidence or worsening of cardiac valve regurgitation with somatostatin analog treatment of acromegaly. J Clin Endocrinol Metab. 2008;93:2243-2248.

21. Mosca S, Paollilo S, Colao A, et al. Cardiovascular involvment in patients affected by acromegaly: an appraisal. Int J Cardiol. 2013;167:1712-1718.

22. Warszawski L, Kasuki L, Sa R, et al. Low frequency of cardiac arrhythmias and lack of structural heart disease in medicallynaive acromegaly patients: a prospective study at baseline and after 1 year of somatostatin analogs treatment. Pituitary. 2016;19:582-589.

23. Klrls A, Erem C, Turan OE, et al. Left ventricular synchronicity is impaired in patients with active acromegaly. Endocrine. 2013;44:200-206.

24. Unubol M, Eryilmaz U, Guney E, et al. QT dispersion in patients with acromegaly. Endocrine. 2013;43:419-423.

25. Dos Santos Sila CM, Lima GA, Volschan IC, et al. Low risk of coronary artery disease in patients with acromegaly. Endocrine. 2015;50:749-755.

26. Dekkers OM, Biermasz NR, Perreira AM, et al. Mortality in acromegaly: a metaanalysis. J Clin Endocrinol Metab. 2008;93:61-67.

27. Giustina A, Barkan A, Beckers A, et al. A consensus on the diagnosis and treatment of acromegaly comorbidities: an update. J Clin Endocrinol Metab. 2020;105:e937-e946.

28. Bernabeu I, Aller J, Alvarez-Escola C, et al. Criteria for diagnosis and postoperative control of acromegaly, and screening and management of its comorbidities: Expert consensus. Endocrinologia, Diabetes y Nutricion (English ed.). 2018;65:297-305. 